\title{
Monitoring of meteorological and hydrological droughts in the Vistula basin (Poland)
}

\author{
Katarzyna Kubiak-Wójcicka (iD) - Bogdan Bąk
}

Received: 29 April 2018 / Accepted: 18 October 2018 /Published online: 30 October 2018

(C) The Author(s) 2018

\begin{abstract}
The article presents the course of meteorological droughts in Vistula subcatchments in years 19812010 and their influence on the occurrence of hydrological droughts. Using the Standardized Precipitation Index (SPI) as an indicator of meteorological drought on the one hand and the Standardized Water-level Index (SWI) and Standardized Runoff Index (SRI) as indicators of hydrological drought on the other, the mutual relationships between precipitation conditions and hydrological conditions were evaluated, as well as the relationships between the two drought types. Studies were conducted for three cumulative periods of these indices, of 12, 24, and 48 months. It was determined that meteorological droughts occurred earliest in the northwestern and central part of the basin, and latest in areas lying above $300 \mathrm{~m}$ a.s.l. and in the south of Poland. Total duration, depending on the cumulative period, for SPI comprised from 38 to $41 \%$ of the analyzed period and for SWI (35-47\%) and SRI (24-51\%). The strongest relationships were identified in the central part of the Vistula $(0.8<r<0.85)$, while the weakest relationships were recorded in the foothill region $(r<0.5)$. There were also indicated non-climate-related factors
\end{abstract}

\footnotetext{
K. Kubiak-Wójcicka $(\bowtie)$

Department of Hydrology and Water Management, Faculty of Earth Sciences, Nicolaus Copernicus University, Lwowska 1, 87-100 Torun, Poland

e-mail:kubiak@umk.pl

B. Bak

Institute of Technology and Life Sciences, Aleja Hrabska 3, 05-090 Falenty, Poland
}

influencing those relationships (underground reservoirs, diverse Vistula water resource usage for municipal and industrial intake).

Keywords Meteorological drought $\cdot$ Hydrological drought · Standardized Precipitation Index (SPI) . Standardized Water-level Index (SWI) · Standardized Runoff Index (SRI) · Vistula basin · Poland

\section{Introduction}

Drought is one of the most destructive natural phenomena, causing significant economic and social damage (Dobrovolski 2015). Contrary to other threats related to climate changes, such as floods, which are usually limited to small regions and often appear at relatively predictable time intervals, droughts are difficult to prognose and their duration and extent are hard to predict (VicenteSerrano and López-Moreno 2005; Tsakiris et al. 2006; Mishra and Singh 2010). Drought is multidimensional. Some studies show that there are a number of bioclimatic comfort zones in which people feel comfortable. The assessment of drought as well as other climatic parameters is very important to determine ideal places for the thermal comfort of humans (Cetin 2015; Cetin et al. 2018a). Recent studies of drought stress, using remote sensing, show monitoring of drought stress and its impact on the assessment of the recreational potential of regions (Cetin et al. 2018b, c). Since the 1970s, there has been an increase in the frequency of meteorological droughts in many parts of Europe, also in Poland, which is attributed 
to climate change (Andréasson et al. 2004; Bordi et al. 2009; Kundzewicz 2009; Seftigen et al. 2013; Šebenik et al. 2017). Towards the end of the twentieth century, frequent occurrences of meteorological and hydrological droughts were identified in many parts of Poland, particularly in the years 1991-2000 (Somorowska 2009).

The problem of both drought types also affects the Vistula (Poland's longest river) and its basin. This has been dealt with by many authors, although these works have been regional in nature (Kubiak-Wójcicka 2012; Bartczak et al. 2014; Meresa et al. 2016). The research by Kępińska-Kasprzak (2015) was a larger work on hydrological droughts of the main rivers of Poland. She analyzed these droughts for 1951-2000 and confirmed the impact of precipitation deficits on the occurrence of hydrological drought from 1 to 2.5 months after the occurrence of a shortage. The reaction time depended, among others, on air temperature increasing evaporation, particularly in the summer. In the case of heavy precipitation, surface waters reacted significantly more quickly than they did to deficits, and the drought usually ended in less than a month. Tokarczyk and Szalińska (2014) studied the course of meteorological and hydrological droughts in Poland's mountain regions and lowlands. They confirmed that precipitation is more variable and hydrological conditions more dynamic in mountain rivers. Meanwhile, in lowlands, the tempo of changes in hydrological conditions is significantly slower; hence, the course and intensity of hydrological drought are more dependent on external factors. Generally, the reaction of catchments to a precipitation deficit is varied and depends primarily on the catchment's physiographic features (permeability, topography, land use, and land cover), climatic conditions (precipitation and evaporation), and human activity (regulation of water levels, collection of water for community, and industrial purposes) (van Loon and Laaha 2015; Bąk and Kubiak-Wójcicka 2016).

The objective of the paper is to describe the Vistula basin in terms of the occurrence of meteorological droughts and hydrological droughts in the years 19812010. The statistics calculated for meteorological droughts made it possible to identify the regions of the Vistula basin most sensitive to such droughts and threshold parameter values for the onset of a drought (those drought parameters being: time of occurrence, drought magnitude, intensity, and sum of precipitation). Similar calculations were also made for the evaluation of hydrological drought.
The aforementioned parameters were identified based on the following drought indices: SPI (Standardized Precipitation Index) for meteorological drought and, for hydrological drought, SWI (Standardized Water-level Index), and SRI (Standardized Runoff Index). One key element of the research was the relations between meteorological and hydrological droughts. One practical result of the paper has been the development of a simple procedure for determining both the intensity of a meteorological drought based on ongoing sums of precipitation and the intensity of a hydrological drought on the Vistula. The knowledge gained may be useful in strategic water management planning in crisis situations (Barker et al. 2015), including on the level of the Vistula basin and on the regional level.

\section{Object of study and study area}

The Vistula is the longest river in Poland, with a length of $1022 \mathrm{~km}$. The area of the basin totals $194,000 \mathrm{~km}^{2}$, representing 54\% of the area of Poland. Approximately $87 \%$ of the basin lies on Polish territory (GUS, Główny Urząd Statystyczny [Central Statistical Office]. Environment 2015). Vistula River is important to the landscape of Poland due to a variety of functions it plays in the region (Kubiak-Wójcicka et al. 2017).

Average Vistula's discharge for the period 19812010 measured on the gauge station in Tczew was $1027 \mathrm{~m}^{3} \mathrm{~s}^{-1}$. The majority of the Vistula basin is decidedly lowland in nature, with altitudes of predominantly up to $300 \mathrm{~m}$ a.s.l. (Fig. 1).

The Vistula has its sources on the slopes of Barania Góra (1106 m a.s.1.) and flows to the Baltic Sea, creating a delta in the Vistula Marshlands. The greatest water resources in the Vistula basin are found in the central Vistula basin, from the San to the mouth of the Narew $(51 \%)$ and in the basin of the upper Vistula (approximately $38 \%$ ). Its greatest tributaries are the following rivers: the San, the Narew and Bug, and the Pilica. There are two man-made reservoirs on the Vistula: the Goczałkowice reservoir is on the upper course of the river and the Włocławek reservoir is on the lower course. In addition to these, the Zegrzyński Lake reservoir on the lower course of the Narew has an influence on hydrological conditions in the middle section of the river (Kubiak-Wójcicka 2018). Along the Vistula, there are several subterranean water bodies, or Major Ground Water Basins (MGWB) which supply water for 


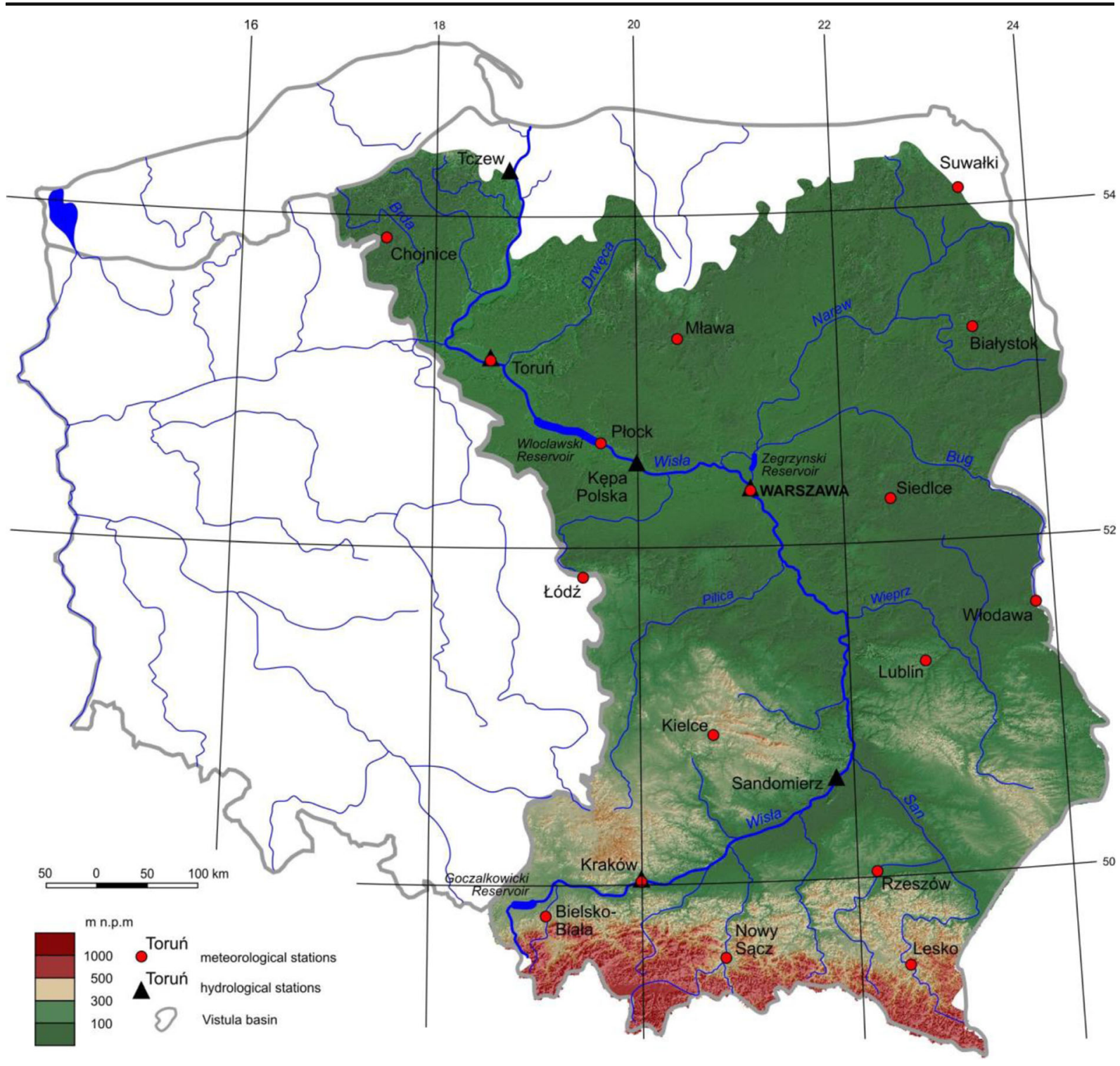

Fig. 1 Vistula River basin

consumption and industrial purposes, particularly around the nation's capital, Warsaw (Kleczkowski 1990).

\section{Climate and hydrological data}

The analysis of meteorological and hydrological droughts used monthly sums of precipitation from 19 meteorological stations and average monthly water levels and runoffs from six hydrological stations. Data were taken from the Institute of Meteorology and Water Management-National Research Institute.

Studies of meteorological droughts in the Vistula basin and hydrological drought on the Vistula were conducted using the index method for the long-term period 1981-2010. These indices were calculated for cumulative periods of 12,24 , and 48 months the total precipitation, average runoff, or average water level.

It was assumed that each gauge station forms a closed subcatchment in which the selected precipitation measurement points are found. At the following locations of gauge stations along the Vistula's course (Fig. 1), the 
number of precipitation stations in the subcatchment was, respectively: Kraków-3, Sandomierz-6, Warsaw Nadwilanówka-11, Kępa Polska-13, Toruń-17, and Tczew-19 (Table 1). SPI-48 calculation in January 1981 for subcatchment capped with gauge station in Torun requires usage of monthly average precipitation values acquired from all 17 meteorological stations located in the subcatchment from 48 preceding months, i.e., since February 1977.

Analysis of precipitation in the Vistula basin showed an uneven distribution on the annual and seasonal scale (Fig. 2a-c). The distribution of annual precipitation in the Vistula basin can be distinguished into four zones. Firstly, the lowest sum of precipitation is found in the belt of lowlands in the center of the country and in the northern part of the Lublin Upland-550-600 mmwhile, secondly, in the northern part of the basin, it is slightly greater, at $600-650 \mathrm{~mm}$. The next two zones are areas above $300 \mathrm{~m}$ a.s.l., with $600-700 \mathrm{~mm}$, and the south of the basin, with 700-1000 mm (Fig. 2a). The average sum of precipitation in the Vistula basin in 1981-2010 was $613 \mathrm{~mm}$. Over the annual course, the driest month was February, with an average sum of precipitation of $29 \mathrm{~mm}$ in the basin, while the wettest were July $(85 \mathrm{~mm})$ and June $(78 \mathrm{~mm})$.

\section{Drought indices}

The index method employed in the study allows the same calculation method to be used for the values of both drought types' indices, in order to determine the same drought parameters and adopt a joint classification of drought intensity (Nalbantis and Tsakiris 2009; Bak and Kubiak-Wójcicka 2016). Additionally, this method makes it possible to evaluate the relationships between precipitation and hydrological conditions in various time periods (months, seasons, years) based on the statistical correlations between index values (Folland et al. 2015).

The SPI index (McKee et al. 1995) used in the work has been widely used in recent years in literature (Nam et al. 2015; Hong et al. 2016; Santos et al. 2017; Zeleňáková et al. 2017). Since 2012, it has also been recommended by the World Meteorological Organization (WMO) for the operational monitoring of drought threats (World Meteorological Organization (WMO)

Table 1 Location of water gauges and gauges in the basin of the Vistula River; source: own study

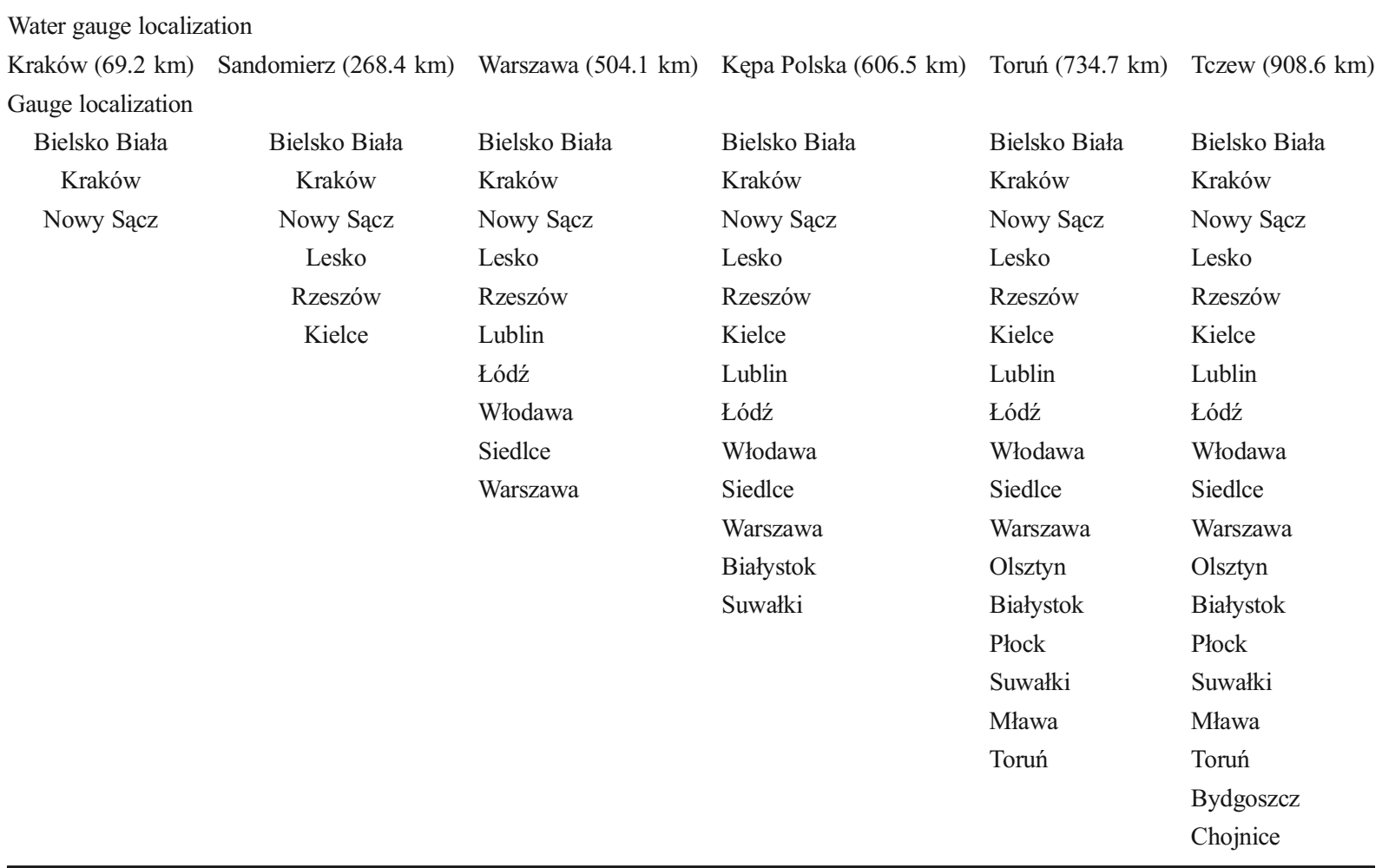




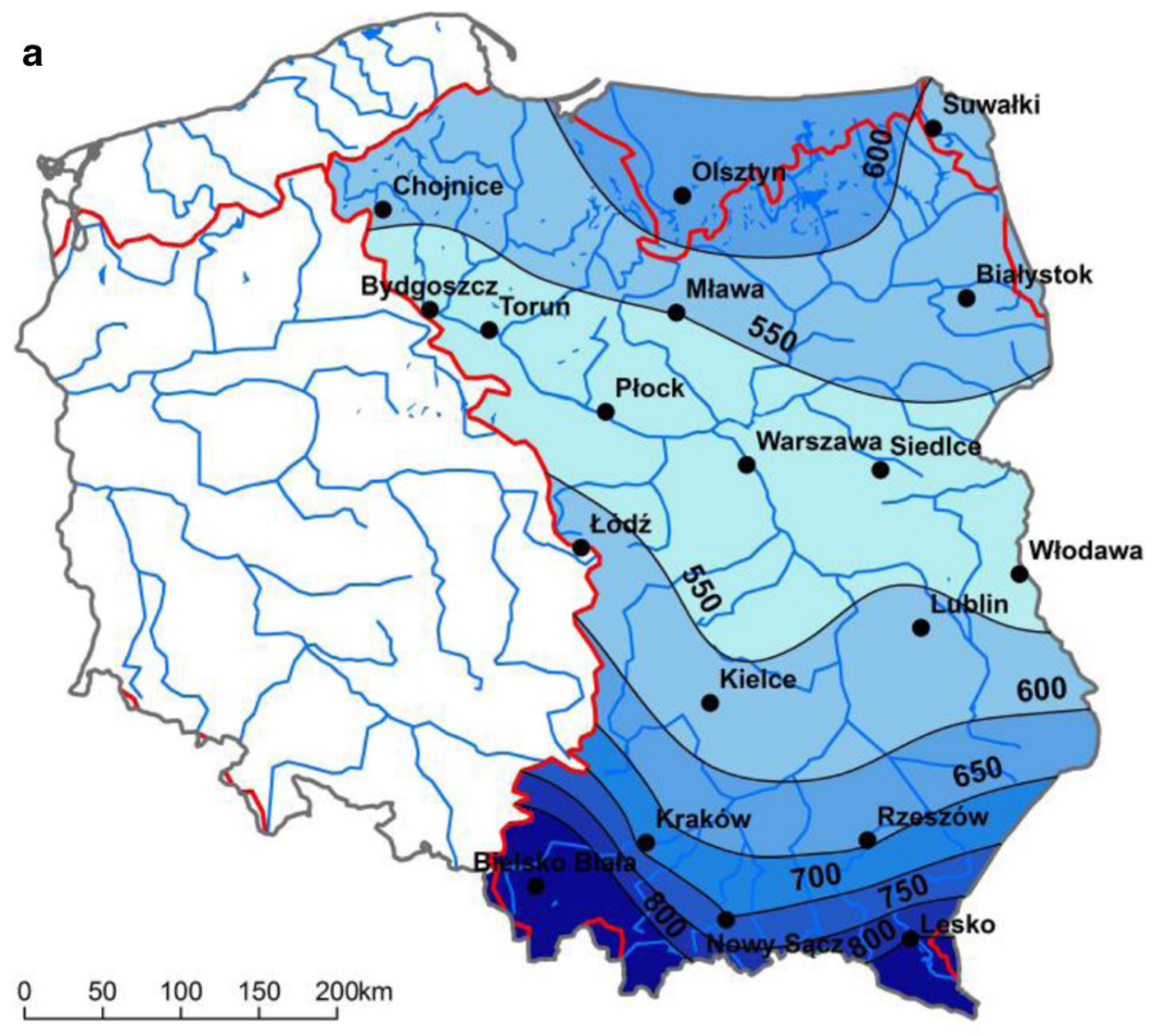

\section{$550600650700750800 \mathrm{~mm}$}

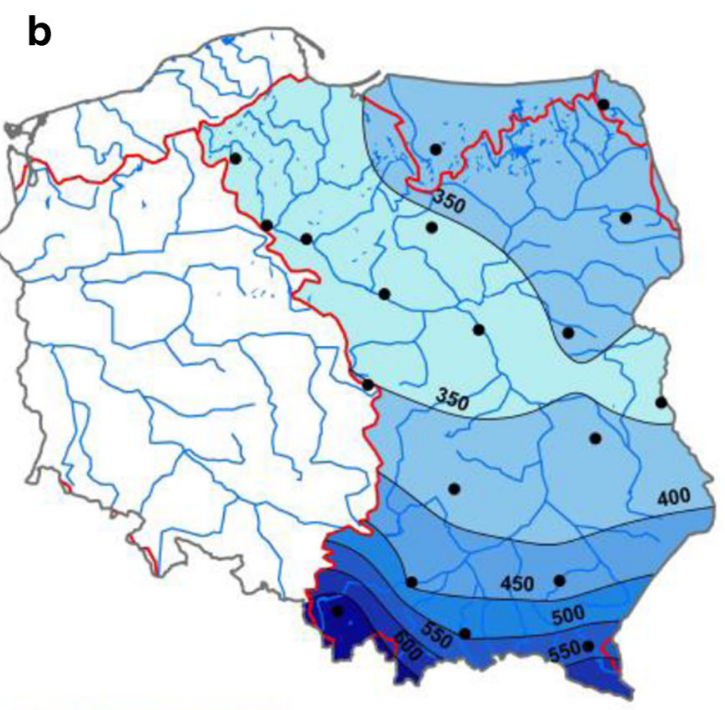

$350400450500550600 \mathrm{~mm}$

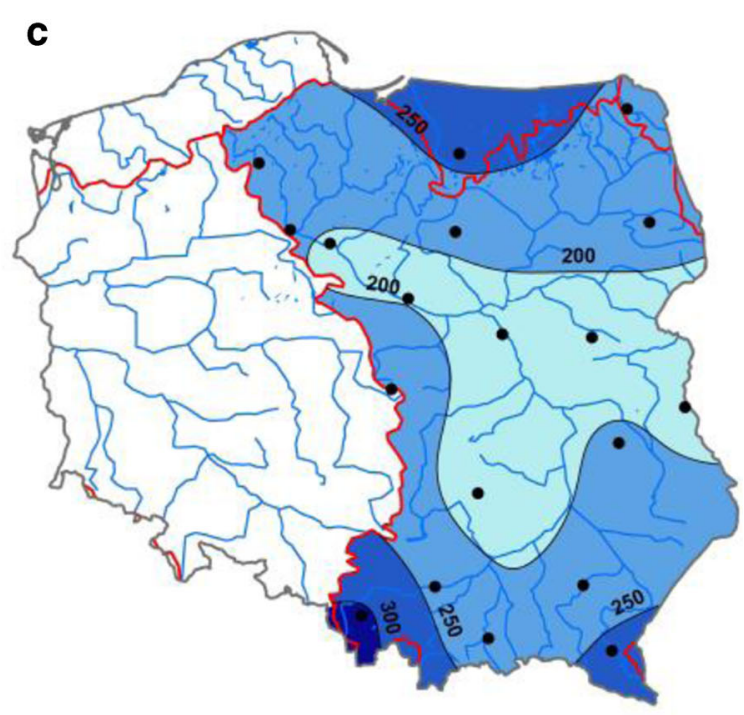

$200250300 \mathrm{~mm}$

Fig. 2 Spatial distributions of average sum of precipitation ( $\mathrm{mm}$ ) in the basin of the Vistula River (1981-2010): a year (Jan-Dec); b summer period (Apr-Sep); c winter period (Oct-Mar); source: own study 
2012). Two indices are taken as hydrological drought indices: SWI, calculated on the basis of water level WL (Sahoo et al. 2015), and SRI, based on data for runoff $R$ (Shukla and Wood 2008; Mishra and Nagarajan 2013; Li et al. 2016; Ljubenkov and Cindrić Kalin 2016; Zou et al. 2018). The values of the indices used are standardized deviations of precipitation, water levels, and runoff from median values for the long-term period. In the work, normal distribution fitting of homogeneous precipitation series was done using the transformer function $f(P)=\sqrt[3]{x}$ (Labędzki 2017). In the case of water levels and runoff, the normalizing function adopted was the two-parameter logarithmic function, In (VicenteSerrano et al. 2012). Conformity of the distribution of the variable transformed by the function $f(P)$ to the normal distribution was tested using the $\chi^{2}$ Pearson test. A positive conformity value allows the index value to be calculated by the formula:

$Z=\frac{f(X)-\hat{\mu}}{\hat{\delta}}$

where: $Z$ is the chosen index ( $S P I, S W I, S R I) ; P, H, R$ are the precipitation, water level, runoff; $f(X)$ is the transformer of precipitation sums, water level, runoff; $\hat{\mu}$ is the mean of normalized $\boldsymbol{X} ; \hat{\delta}$ is the standard deviation of normalized $\boldsymbol{X}$.

After McKee et al. (1995), it was assumed that, in a drought spell, all values of the indices SPI, SWI, and SRI are negative and, at the same time, in at least 1 month are less than or equal to -1.0 . The drought is broken if an index value goes above zero. The identified drought spells can most commonly be described with the adopted drought parameters: the drought parameters were as follows:

$N$ number of droughts.

$D$ duration [months].

Time [\%] percentage of total time of drought spells. $\max D$ [months] duration of longest drought. $\min D$ [months] duration of shortest drought.

$D M$ total drought magnitude (sum of SPI values for all drought spells).

$I[D M / D]$ intensity.

For indices whose values fulfill the condition $X<-$ 1.0 a joint, three-class evaluation of drought intensity was adopted: moderately dry $(-1.00$ to -1.49$)$, severely dry $(-1.50$ to -1.99$)$, and extremely dry $(\leq 2.0)$.
The work uses series of cumulative sums of precipitation, water levels, and runoff as suggested in the literature for 12-, 24-, and 48-month periods, given as $(P-12, W L-12, R-12, \ldots, P-48, W L-48, R-48)$. Depending on the length of measurement series, the calculated drought index values were given the relevant designations (SPI-12, SWI-12, SRI-12, .., SPI-48, SWI-48, SRI48). The relationships between the indices $S P I-n$ and $S W I$-n and between SPI-n and SRI-n ( $n$ number of cumulative months) were evaluated using the correlation coefficients for successive months of the calendar year and for the entire year.

\section{Results}

Droughts in the years 1981-2010

\section{Meteorological droughts}

Based on the distribution of SPI-12 index values in the study period, an area of the northern part of the basin was distinguished in which the total duration of droughts was shortest, at $24 \%$ of the total multiannual period, and in the central part of the basin and in the south two areas were identified where droughts lasted decidedly longer, i.e., $48 \%$ of the total study period. This difference in the total duration of droughts was 85 months. In the longer cumulative period of precipitation (SPI-24), droughts occurred most briefly in the northern and northwestern part of the basin, i.e., for $32 \%$ of the total study period. In the center and east of the Vistula basin, this time was at least 5 to $7 \%$ longer, while in the middle of the basin, it was maximum $46 \%$. For SPI-48, the shortest total drought duration occurred in the belt of lowlands running from the northwestern extent of the basin to the center of the country and in the northern part of the Vistula basin, with a minimum of $31 \%$. Significantly longer periods were identified in the south and eastern limits of the basin, with a maximum of $51 \%$. The lowest total drought magnitudes $(|\mathrm{DM}|)$ for all variations of the SPI indicator were observed in the north-western and northern part of the Vistula basin. In eastern Poland, these were clearly greater, which may be explained by the longer durations of the phenomena (Fig. 3). 

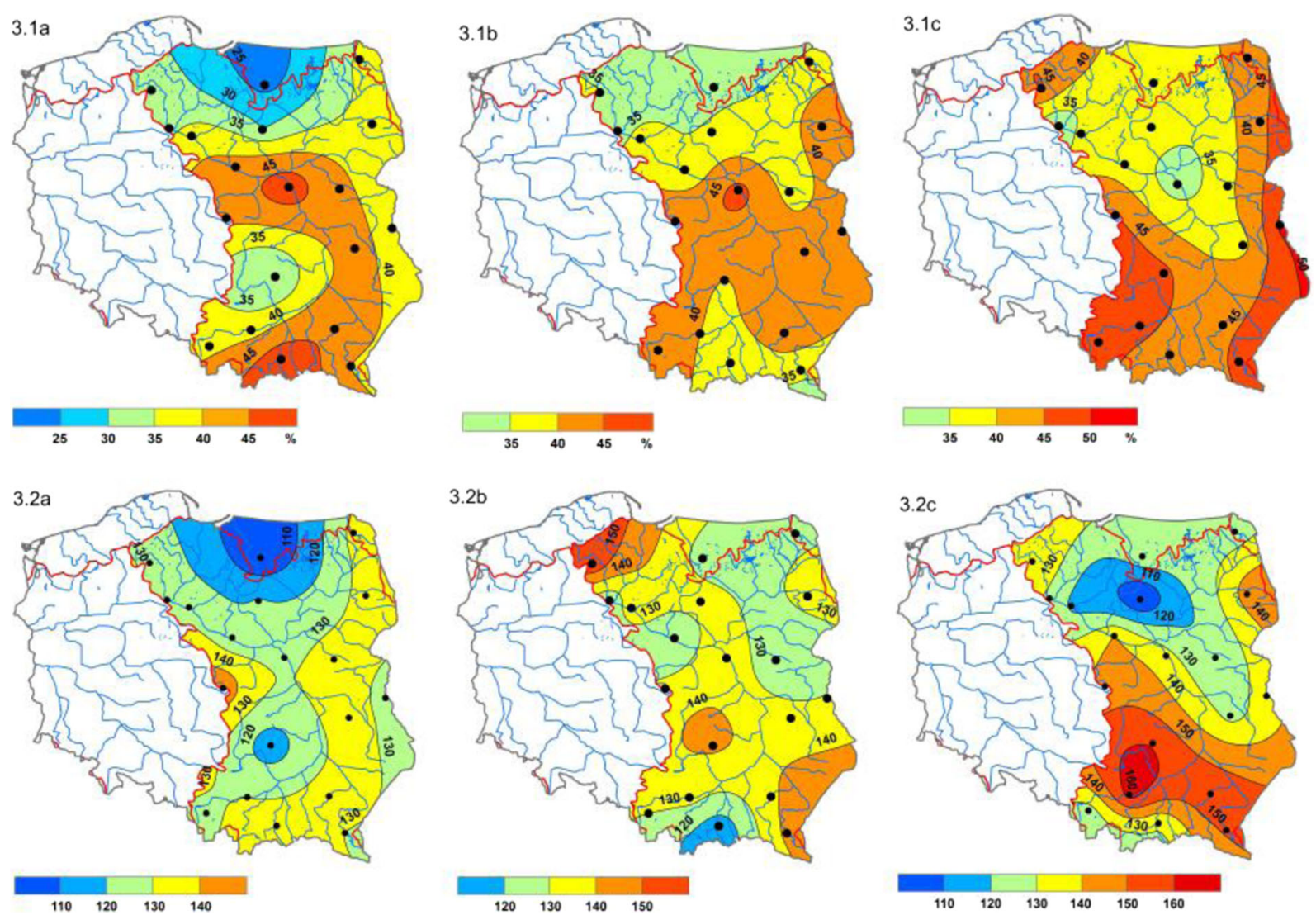

Fig. 3 Spatial distributions of drought duration as percentage of total time (1): 1a $S P I-12 ; \mathbf{1 b} S P I-24$; $\mathbf{1 c} S P I-48$ and total drought magnitude DM (2) in the basin of the Vistula River (1981-2010): 2a SPI-12; 2b SPI-24; 2c SPI-48; source: own study

\section{Hydrological droughts}

Hydrological droughts on the Vistula, as determined by the SWI-n index, occurred several times during the longterm study period. Using a longer period for averaging water levels reduced the number of droughts over the long-term period. The total drought duration ranged from 33 to $46 \%$ for $S W I-12$, from 32 to $54 \%$ for $S W I-$ 24 , and from 38 to $43 \%$ for $S W I-48$. The longest individual hydrological droughts as determined by the $S W I-$ 48 index lasted for around 150 months. Drought intensity in the long-term period ranged from -0.8 to -1.3 (depending on index). The strongest droughts were found in the center of Poland (Warsaw), and the weakest in Sandomierz. The reason for that may be huge water intake in Warsaw and, on the other hand, a large number of mountain tributaries feeding Vistula between Kraków and Sandomierz.

In most cases, the number of hydrological drought spells according to the $S R I-\mathrm{n}$ index was similar to the number of drought spells according to SWI-n. The greatest number of drought periods was recorded at Sandomierz (6; SWI-12). Over various time frames, cases of 1-month-long droughts were also recorded, in Warsaw, Kępa Polska, and Tczew. Also, for this index, total hydrological drought duration was variable, ranging from 23 to $48 \%$ between selected measurement points. The longest single drought lasted 151 months, and the shortest, 16. Drought intensity ranged from 0.8 to -1.3 .

Averaged values of the statistics for meteorological and hydrological droughts are presented in Table 2.

The course of meteorological and hydrological droughts and their interrelations

An example of parallel courses of meteorological and hydrological droughts in subcatchments is shown for the measurement station at Kępa Polska (Fig. 4). The choice of this location was dictated by the fact that the Vistula's 
Table 2 Statistics of mean parameter values for meteorological and hydrological droughts; source: own study

\begin{tabular}{|c|c|c|c|c|c|c|c|}
\hline Index & $N$ & Time $[\%]$ & $D$ [months] & $\max D[$ months $]$ & $\min D[$ months $]$ & Total $D M$ & $I$ \\
\hline SPI-12 & 7 & 38 & 137 & 38 & 6 & 128 & -1.0 \\
\hline SPI-24 & 4 & 39 & 140 & 66 & 15 & 132 & -0.9 \\
\hline SPI-48 & 2 & 42 & 149 & 105 & 28 & 136 & -0.9 \\
\hline SWI-12 & 3 & 39 & 141 & 84 & 21 & 135 & -1.0 \\
\hline SWI-24 & 3 & 43 & 155 & 93 & 35 & 145 & -1.0 \\
\hline$S W I-48$ & 1 & 41 & 147 & 126 & 61 & 140 & -1.0 \\
\hline SRI-12 & 4 & 39 & 139 & 73 & 20 & 118 & -0.8 \\
\hline SRI-24 & 3 & 47 & 168 & 84 & 31 & 134 & -0.8 \\
\hline$S R I-48$ & 1 & 34 & 122 & 112 & 47 & 110 & -0.9 \\
\hline
\end{tabular}

channel over this section is unmanaged and natural; there is no influence of any water reservoir and it is located beyond the reach of MGWB underground reservoirs. This station covers $87 \%$ of the total area of the Vistula basin.

This example shows that meteorological and hydrological drought spells significantly coincided with one another over the long-term period. The 12-month cumulative period for precipitation and averaged water levels and runoff had a greater variability of drought indices, which caused the total duration of simultaneous occurrence of both drought types to be shortest for this cumulative period. In the longer periods (24 and 48 months), the duration of simultaneous occurrence was longer.

The extent of correlation between precipitation and hydrological conditions at all stations was established by calculating the correlation coefficients $r$ of SPI-n to $S W I-n$ and of SPI-n to SRI-n. This study was done in two variants: for the relationships of all index values in successive months and on the annual scale and for the relationships in the period limited only to meteorological drought spells and both kinds of hydrological drought.

The data presented in Table 3 show the dependence of hydrological conditions on precipitation to be highly variable. The minimum value of $r$ was 0.28 , and the maximum was 0.92 . It is important to note here that in most cases, the correlations were high $(0.7<r<0.9)$. Such relationships are exemplified at, inter alia, Sandomierz: SPI-12 to SWI-12 $(r=0.72), S P I-12$ to SRI-12 $(r=0.88), S P I-24$ to SRI-24 $(r=0.89)$, and in Tczew: $S P I-12$ to $S W I-12$ ( $r=0.77), S P I-24$ to $S W I-24$ $(r=0.83), S P I-48$ to $S W I-48(r=0.86)$. Only in Kraków, in the upper course of the Vistula, were values of $r$ smaller for all variants. Here, the greatest correlation was found between SPI-12 and SWI-12 $(r=0.63)$.

Such diverse results were also obtained in studies of the relationship between droughts and their time of occurrence. On all gauge stations, the values of $r$ in the periods of parallel appearance of both kinds of droughts were enclosed in the range of $0.62<r<0.70$. These can be broken down into three groups: very weak or no relationship $(r<0.5)$, moderate relationship $(0.5<$ $r<0.6)$, and good relationship $(r>0.6)$ (Bachmair et al. 2015).

Threshold of drought and nomograms

The joint classification of drought spells adopted in the work allowed threshold values to be determined for the analyzed parameters of classes of drought, using an inversion of formula 1. An example of maps of the distribution of threshold precipitation values for the onset of drought (SPI $=-1.0)$ in the adopted cumulative periods of precipitation is presented in Fig. 4.

Transforming the formula [1] to the form of [2], threshold precipitation values $P-n(n=12$. 24. 48) may be calculated in each precipitation gauge in the Vistula basin, below which moderate $(S P I-n=-1.0)$, severe $(S P I-n=-1.5)$, and extreme $(S P I-n=-2.0)$ droughts begin:

$P=(S P I \cdot \mu+\delta)^{3}$

where:

$P \quad$ threshold of drought beginning (mm), 
Fig. 4 Course of SPI, SWI, and SRI at the Kępa Polska hydrological gauge in the accumulation periods of $\mathbf{a} 12, \mathbf{b}$ 24 , and c 48 months a)

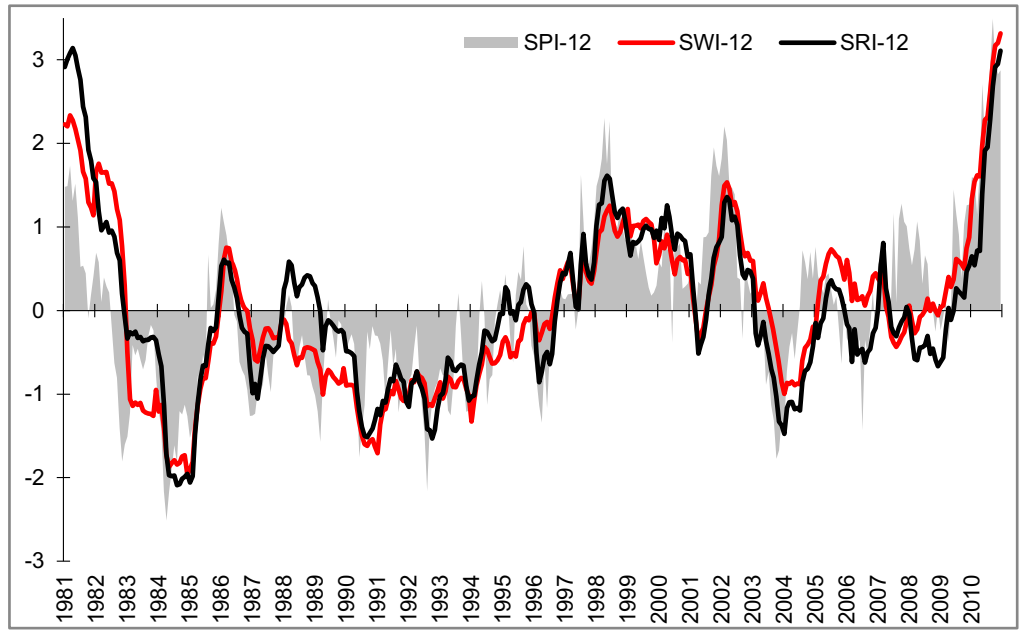

b)

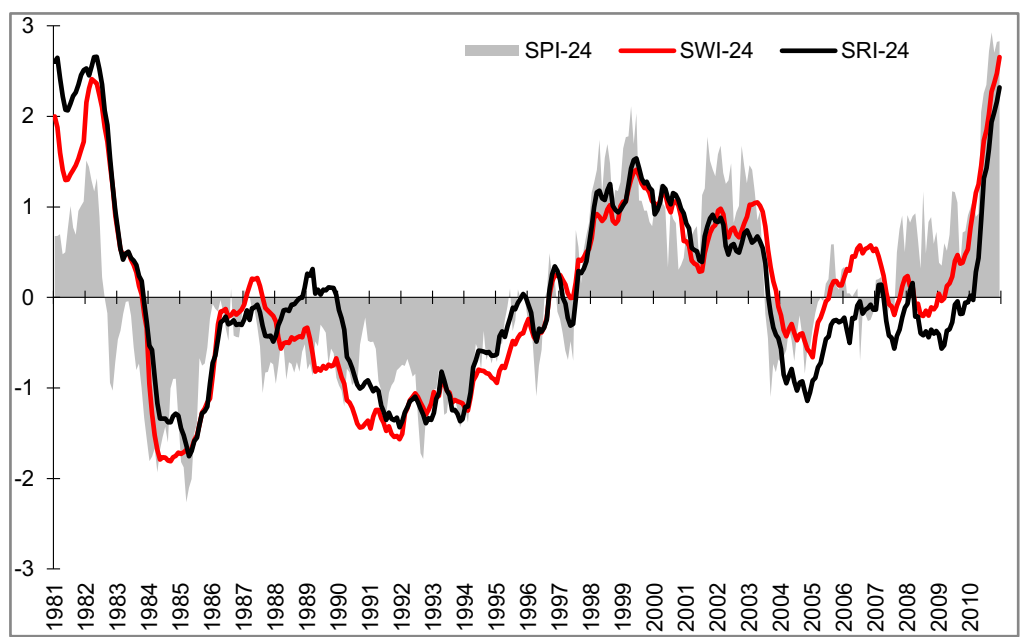

c)

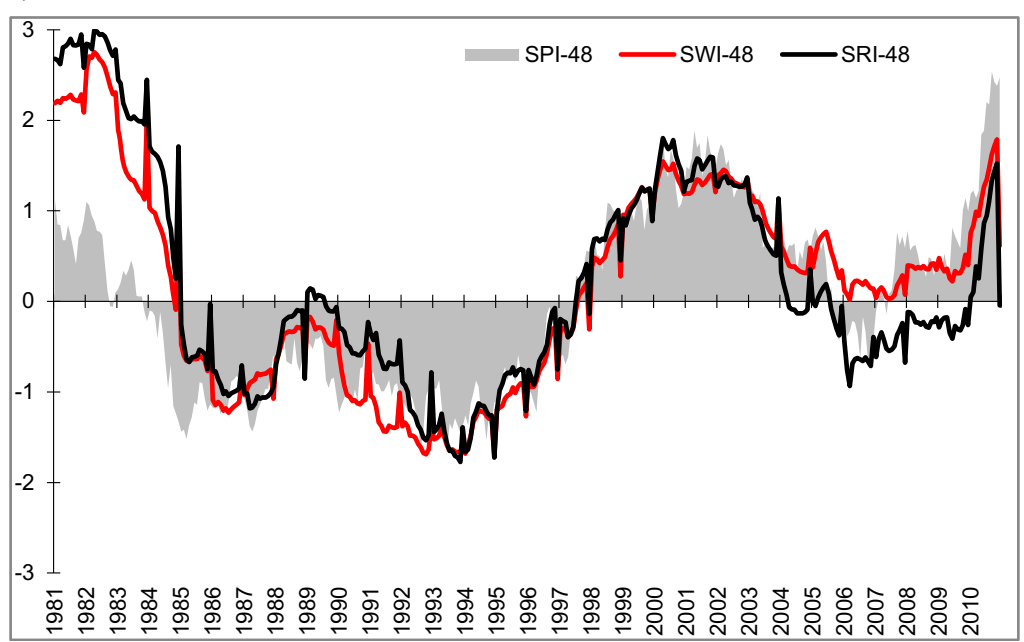


Table 3 Correlation coefficients: $S P I$-n to $S W I$-n and $S P I$-n to $S R I$-n $(n=12,24,24)$; source: own study

\begin{tabular}{|c|c|c|c|c|c|c|c|c|c|c|c|c|c|}
\hline & I & II & III & IV & $\mathrm{V}$ & VI & VII & VIII & IX & $\mathrm{X}$ & $\mathrm{XI}$ & XII & I-XII \\
\hline \multicolumn{14}{|c|}{ Kraków } \\
\hline SPI-12 vs. SWI-12 & 0.66 & 0.63 & 0.65 & 0.63 & 0.58 & 0.59 & 0.62 & 0.57 & 0.61 & 0.65 & 0.65 & 0.67 & 0.63 \\
\hline SPI-24 vs. SWI-24 & 0.55 & 0.57 & 0.59 & 0.57 & 0.52 & 0.54 & 0.57 & 0.49 & 0.52 & 0.53 & 0.54 & 0.56 & 0.54 \\
\hline SPI-48 vs. SWI-48 & 0.42 & 0.42 & 0.43 & 0.41 & 0.38 & 0.40 & 0.46 & 0.42 & 0.39 & 0.40 & 0.40 & 0.28 & 0.40 \\
\hline \multicolumn{14}{|c|}{ Sandomierz } \\
\hline SPI-12 vs. SWI-12 & 0.77 & 0.78 & 0.76 & 0.73 & 0.71 & 0.70 & 0.66 & 0.66 & 0.68 & 0.68 & 0.72 & 0.79 & 0.72 \\
\hline SPI-12 vs. SRI-12 & 0.91 & 0.91 & 0.91 & 0.89 & 0.90 & 0.88 & 0.84 & 0.84 & 0.86 & 0.86 & 0.87 & 0.92 & 0.88 \\
\hline SPI-24 vs. SWI-24 & 0.63 & 0.66 & 0.67 & 0.64 & 0.64 & 0.66 & 0.63 & 0.62 & 0.62 & 0.62 & 0.65 & 0.69 & 0.64 \\
\hline SPI-24 vs. SRI-24 & 0.88 & 0.88 & 0.90 & 0.89 & 0.90 & 0.90 & 0.87 & 0.86 & 0.87 & 0.88 & 0.89 & 0.91 & 0.89 \\
\hline SPI-48 vs. SWI-48 & 0.53 & 0.53 & 0.53 & 0.50 & 0.49 & 0.51 & 0.53 & 0.49 & 0.47 & 0.48 & 0.49 & 0.29 & 0.49 \\
\hline SPI-48 vs. SRI-48 & 0.87 & 0.87 & 0.88 & 0.87 & 0.87 & 0.88 & 0.88 & 0.87 & 0.86 & 0.87 & 0.87 & 0.66 & 0.86 \\
\hline \multicolumn{14}{|c|}{ Warsaw } \\
\hline SPI-12 vs. SWI-12 & 0.54 & 0.54 & 0.57 & 0.52 & 0.53 & 0.54 & 0.54 & 0.53 & 0.46 & 0.49 & 0.47 & 0.54 & 0.52 \\
\hline SPI-12 vs. SRI-12 & 0.86 & 0.86 & 0.86 & 0.80 & 0.83 & 0.80 & 0.74 & 0.82 & 0.81 & 0.79 & 0.81 & 0.86 & 0.82 \\
\hline SPI-24 vs. SWI-24 & 0.56 & 0.56 & 0.59 & 0.55 & 0.56 & 0.54 & 0.55 & 0.54 & 0.51 & 0.52 & 0.50 & 0.54 & 0.54 \\
\hline SPI-24 vs. SRI-24 & 0.82 & 0.83 & 0.85 & 0.85 & 0.85 & 0.85 & 0.80 & 0.83 & 0.81 & 0.81 & 0.84 & 0.86 & 0.83 \\
\hline SPI-48 vs. SWI-48 & 0.61 & 0.61 & 0.62 & 0.60 & 0.61 & 0.60 & 0.61 & 0.63 & 0.61 & 0.62 & 0.59 & 0.64 & 0.61 \\
\hline SPI-48 vs. SRI-48 & 0.84 & 0.84 & 0.85 & 0.84 & 0.83 & 0.85 & 0.85 & 0.81 & 0.80 & 0.81 & 0.82 & 0.58 & 0.81 \\
\hline \multicolumn{14}{|c|}{ Kępa Polska } \\
\hline SPI-12 vs. SWI-12 & 0.78 & 0.79 & 0.81 & 0.78 & 0.82 & 0.77 & 0.68 & 0.73 & 0.70 & 0.66 & 0.68 & 0.78 & 0.75 \\
\hline SPI-12 vs. SRI-12 & 0.68 & 0.70 & 0.74 & 0.71 & 0.75 & 0.70 & 0.59 & 0.64 & 0.62 & 0.56 & 0.59 & 0.68 & 0.66 \\
\hline SPI-24 vs. SWI-24 & 0.83 & 0.87 & 0.89 & 0.86 & 0.90 & 0.86 & 0.78 & 0.79 & 0.75 & 0.72 & 0.75 & 0.83 & 0.82 \\
\hline SPI-24 vs. SRI-24 & 0.71 & 0.74 & 0.77 & 0.79 & 0.81 & 0.80 & 0.73 & 0.73 & 0.70 & 0.68 & 0.71 & 0.76 & 0.74 \\
\hline SPI-48 vs. SWI-48 & 0.86 & 0.87 & 0.87 & 0.85 & 0.87 & 0.87 & 0.84 & 0.82 & 0.79 & 0.78 & 0.80 & 0.61 & 0.82 \\
\hline SPI-48 vs. SRI-48 & 0.72 & 0.73 & 0.75 & 0.73 & 0.74 & 0.75 & 0.74 & 0.69 & 0.66 & 0.66 & 0.68 & 0.43 & 0.69 \\
\hline \multicolumn{14}{|c|}{ Toruń } \\
\hline SPI-12 vs. SWI-12 & 0.60 & 0.62 & 0.65 & 0.61 & 0.64 & 0.58 & 0.47 & 0.50 & 0.47 & 0.44 & 0.49 & 0.58 & 0.55 \\
\hline SPI-12 vs. SRI-12 & 0.74 & 0.77 & 0.80 & 0.77 & 0.82 & 0.75 & 0.66 & 0.70 & 0.64 & 0.61 & 0.63 & 0.73 & 0.72 \\
\hline SPI-24 vs. SWI-24 & 0.52 & 0.55 & 0.57 & 0.57 & 0.57 & 0.55 & 0.48 & 0.45 & 0.42 & 0.40 & 0.45 & 0.49 & 0.50 \\
\hline SPI-24 vs. SRI-24 & 0.70 & 0.73 & 0.76 & 0.78 & 0.80 & 0.78 & 0.71 & 0.70 & 0.67 & 0.64 & 0.67 & 0.72 & 0.72 \\
\hline SPI-48 vs. SWI-48 & 0.48 & 0.49 & 0.49 & 0.47 & 0.45 & 0.46 & 0.46 & 0.39 & 0.34 & 0.35 & 0.37 & 0.16 & 0.41 \\
\hline SPI-48 vs. SRI-48 & 0.71 & 0.72 & 0.74 & 0.73 & 0.73 & 0.74 & 0.71 & 0.67 & 0.63 & 0.63 & 0.64 & 0.38 & 0.67 \\
\hline \multicolumn{14}{|c|}{ Tczew } \\
\hline SPI-12 vs. SWI-12 & 0.81 & 0.83 & 0.86 & 0.83 & 0.87 & 0.79 & 0.73 & 0.75 & 0.67 & 0.67 & 0.69 & 0.79 & 0.77 \\
\hline SPI-12 vs. SRI-12 & 0.70 & 0.73 & 0.78 & 0.75 & 0.79 & 0.71 & 0.60 & 0.64 & 0.59 & 0.56 & 0.58 & 0.68 & 0.68 \\
\hline SPI-24 vs. SWI-24 & 0.83 & 0.86 & 0.88 & 0.88 & 0.90 & 0.86 & 0.83 & 0.82 & 0.76 & 0.75 & 0.78 & 0.82 & 0.83 \\
\hline SPI-24 vs. SRI-24 & 0.65 & 0.68 & 0.72 & 0.73 & 0.76 & 0.73 & 0.66 & 0.64 & 0.61 & 0.58 & 0.61 & 0.66 & 0.67 \\
\hline SPI-48 vs. SWI-48 & 0.90 & 0.91 & 0.91 & 0.91 & 0.92 & 0.92 & 0.89 & 0.87 & 0.83 & 0.84 & 0.85 & 0.64 & 0.86 \\
\hline SPI-48 vs. SRI-48 & 0.66 & 0.68 & 0.69 & 0.68 & 0.69 & 0.69 & 0.66 & 0.62 & 0.58 & 0.57 & 0.58 & 0.34 & 0.62 \\
\hline
\end{tabular}

$\mu$ mean of normalized precipitation,

$\delta$ standard deviation of normalized precipitation; source: own study.
The results achieved in the study show that meteorological drought in the Vistula basin did not appear at the same time as hydrological drought. It was ascertained 
that at each meteorological station, the precipitation threshold value for a drought was different. In the south of Poland (mountain region), the thresholds were the highest. For example, meteorological drought in Bielsko Biała appeared when 12-month precipitation sum was less than $814 \mathrm{~mm}$ while in Nowy Sacz $613 \mathrm{~mm}$. In the highlands, the thresholds were much lower, e.g., in Kraków $560 \mathrm{~mm}$ and in Lublin $491 \mathrm{~mm}$. The lowest threshold values were found in lowlands of central Poland: in Bydgoszcz $405 \mathrm{~mm}$ and in Torun $424 \mathrm{~mm}$. Threshold values calculated for longer intervals were proportionally greater than the values for 12-month periods. For example, in Warsaw, the threshold for meteorological drought SPI-12 was $574 \mathrm{~mm}$, SPI-24 $1178 \mathrm{~mm}$, and SPI-48 $2043 \mathrm{~mm}$.

Average precipitation of all meteorological stations in a given subcatchment was assumed the threshold precipitation values. In the 12-month period, threshold precipitation levels in particular subcatchments were Kraków 673 mm, Sandomierz 632, Warsaw 574, Kępa Polska 572, Torun 560, Tczew 555. Similar calculation method was applied to hydrological gauge stations. In the same period, the threshold water level in Warsaw was $2285 \mathrm{~cm}$ and the threshold discharge $5229 \mathrm{~m}^{3} \mathrm{~s}^{-1}$. In 24-month period, the values were, respectively, $4643 \mathrm{~cm}$ and $9680 \mathrm{~m}^{3} \mathrm{~s}^{-1}$, and in 48-month period: $9466 \mathrm{~cm}$ and $19,554 \mathrm{~m}^{3} \mathrm{~s}^{-1}$.

Nomogram usage is simple. On the vertical axis, one marks either cumulated precipitation sum or water level or discharge, respectively. Casting the value on the linear regression chart allows determination of an appropriate index' value on the horizontal axis (Fig. 5).

In the subcatchments, in which relationship between both types of drought were strong, there is a linear relation between the values of cumulated precipitation sums, water levels and discharges, and the corresponding index values. Usage of the nomograms facilitates monitoring of both drought type intensity. Depending on subcatchment location, the threshold values of cumulated precipitation sums, water levels, and discharges are different and depend on the assumed time scale. The examples prepared for the subcatchment in Sandomierz for 48-month period have been presented in Fig. 5.

\section{Discussion}

The paper aims to identify the occurrence of hydrological drought in relation to meteorological droughts in
Poland in the period 1981-2010. The analyzed problem is part of the latest research trend towards developing different approaches to the assessment and identification of drought. For the first time, the problem of drought in Poland was considered over a larger spatial scale, i.e., the Vistula River Basin, using the index method. The index method which was used includes identification of meteorological and hydrological droughts.

Data analysis showed that the lowest sums of precipitation and most frequent meteorological droughts occurred in central and central-eastern Poland. Similar results are given by Doroszewski et al. (2014), who analyzed the distribution of meteorological droughts in Poland for 1961-2010. Asymmetric precipitation distribution over Vistula basin has been presented on Fig. 1bd. It may be assumed that the Vistula is a natural border between humid air flowing from the Atlantic Ocean and dry, continental air flowing from Russia. That fact is confirmed by precipitation distribution studies in Central Europe and Poland which have been conducted in 2nd half of 20th century and at the beginning of 21st century (Marosz et al. 2011). The extensive meteorological droughts in the Vistula basin in the years 1983, 2000, 2003, and 2006, identified in the work, formed part of a cross-border drought area extending beyond the borders of Poland (Rimkus et al. 2012, 2013; Vido et al. 2015).

The existence of extensive droughts across Europe in the years 1950-2012 has been confirmed by the research of Spinoni et al. (2015), who analyzed the occurrence of droughts in Europe based on the SPI-12 index. They divided Europe into 13 regions, with Poland classified into Eastern Europe (along with Bulgaria, Czech Republic, Hungary, Romania, Slovak Republic). They determined that eight long-term droughts occurred in their study period, including six droughts in the years 1991-2010. In the neighboring Ex-USSR region (Belarus, Moldova, Ukraine), they identified six droughts, and four in the Baltic Republics (Estonia, Latvia, Lithuania). The results of the current paper showed variable precipitation in the Vistula basin, typical of the distribution of precipitation in neighboring regions. It would appear that, due to the similarity of rainfall distribution and occurrence of droughts, the eastern part of the Vistula basin may be analyzed together with the ExUSSR region and the north-eastern part together with the Baltic Republics. A significant part of the Vistula basin is made up of right tributaries in eastern Poland, constituting half of the water resources of the river 
Fig. 5 Nomograms to determine parameters of droughts: a meteorological $(\mathrm{P} \rightarrow \mathrm{SPI})$; b hydrological $(\mathrm{WL} \rightarrow \mathrm{SWL})$; hydrological $(\mathrm{R} \rightarrow \mathrm{SRI})$ for Sandomierz hydrological gauge; source: own study a)

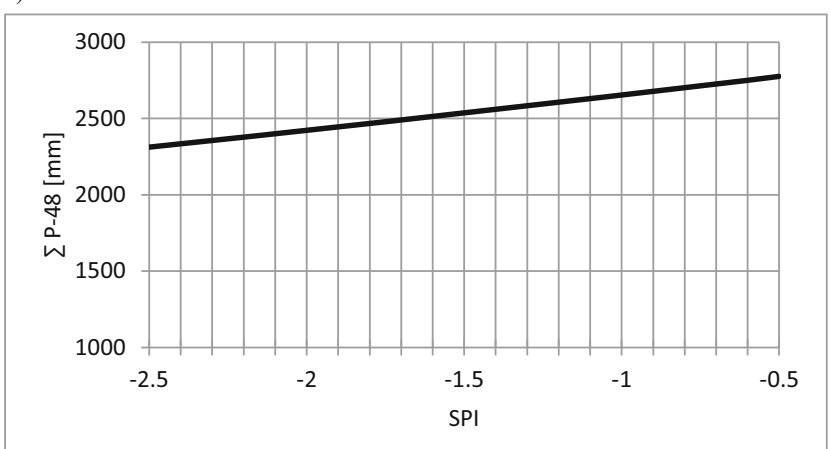

b)

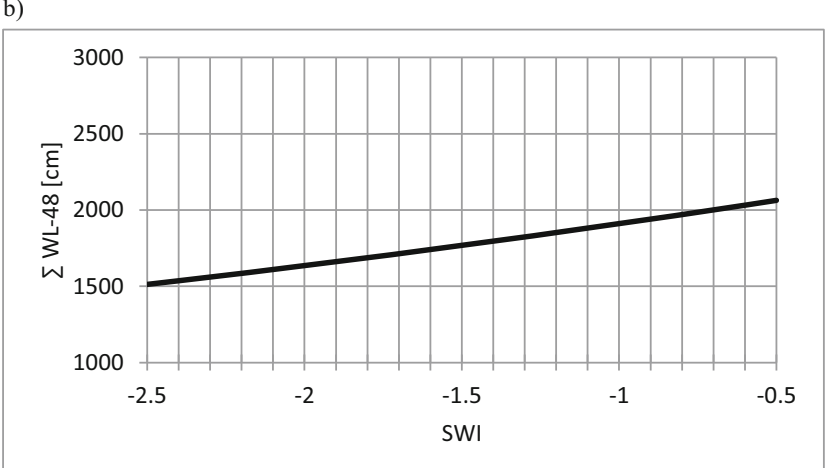

c)

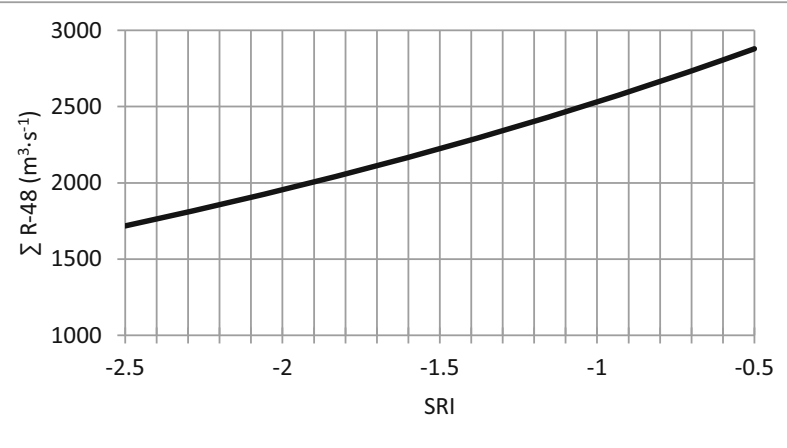

basin. In turn, hydrological droughts in the upper course of the Vistula, which covers the southern part of the basin, are dependent on the extent of precipitation in the Carpathians (Fal 2007; Vido et al. 2015).

Analysis herein of the distribution of meteorological and hydrological droughts identified the following instances:

(1) no meteorological or hydrological droughts (e.g., in 1981, 1999, and 2001),

(2) meteorological droughts (Toruń: June 1984Dec 1990),
(3) hydrological drought without meteorological drought (Tczew: Sep 2003-Mar 2010),

(4) concurrent meteorological and hydrological droughts (Warszawa: Jan 1985-Dec 1992; Kępa Polska: Jan 1985-June 1997). The above cases were also observed in other regions of Europe at the turn of the twenty-first century (Blauhut et al. 2015).

This work analyzed the course of hydrological droughts over the annual course because ice phenomena appear on the Vistula River in the winter (although 
sporadically in recent years and never along the whole length of the river) (Cyberski et al. 2006; Pawłowski 2009). Cases of river beds freezing and long-term ice phenomena, i.e., lasting from late autumn to the beginning of spring, were recorded in the southern and eastern part of the Vistula basin. The problem of frozen rivers was also noted by Rimkus et al. (2013), who studied the relationship between meteorological and hydrological droughts in the Neman river basin (Lithuania, Latvia). Those authors suggested in such cases investigating dependences during periods of free water flow only, i.e., in summer and autumn. In the case of the Vistula, the minimum average monthly water levels were most frequently observed in those very periods and were one third lower than the average monthly values in the longterm study period. Meanwhile, minimum average monthly runoff in summer and autumn was half the average for the long-term study period.

In analyzing the interrelations of both drought types, it is important to take into account non-climatic factors which may locally influence the Vistula's hydrological regime (Tokarczyk and Szalińska 2014; Bąk and Kubiak-Wójcicka 2017). According to van Loon and Laaha (2015), there are more than 30 factors in a catchment that can influence the occurrence of hydrological drought. Examples of such influences can also be found in the Vistula basin. These include the influence that man-made reservoirs, such as the Goczałkowice, or, to a lesser degree, the Włocławek reservoir and the other reservoirs on the tributaries of the Vistula have on the Vistula's hydrological regime. In addition, a lot of water is extracted at Warsaw for consumption and industrial purposes. Around the analyzed water gauges and their surrounding areas, there are groundwater reservoirs of various capacities which significantly contribute to the Vistula channel during precipitation deficits.

Dramatic changes in the interactions between external factors in the Vistula basin, and also the appearance of extreme climatic conditions in the Vistula basin, may have an influence on the appearance or disappearance of a hydrological drought, regardless of the existence of a meteorological drought. This is most frequently observed over short periods of 1 to 3 months. The large area of the Vistula basin and the role of groundwaters in the feeding of the river channel determine the significant hydrological inertia of the river. For this reason, the long cumulative precipitation periods $(12,24$, and 48 months) which were adopted cause the relations between meteorological and hydrological droughts to be large $(r>0.7)$. The small correlation coefficients between droughts identified in the Neman river basin may result from the adoption of too short a cumulative precipitation period. Shorter cumulative periods (under 12 months) are most commonly used in small catchments in a dry and Mediterranean climate (Loukas and Vasiliades 2004; Haslinger et al. 2014). In many cases, the $r$ values obtained were higher than the assumed threshold values, and these relationships can be considered very strong (Bachmair et al. 2015).

The practical dimension of this work resides in the attached nomograms, which allow values of a meteorological and hydrological drought index to be determined based on the sum of precipitation over the given periods of time. The nomograms proposed by the authors are new and were inspired by the work of Bak (2006), who used similar nomograms, based on current precipitation, to determine the relationship between precipitation and a meteorological drought, and between meteorological drought and agricultural drought. In turn, Al-Faraj et al. (2014) used nomograms to determine drought index values: RDIst (Standardized Reconnaissance Drought Index) and SDI (Streamflow Drought Index) depending on changes in precipitation and potential evaporation. In the case of the Vistula basin, the proposed nomograms are useful in, for example, predicting the intensity of particular types of drought. Such knowledge may be valuable for, among others, decision-making water management bodies.

Vistula River and its basin is an important source of water for the community and the economy. Water resources in Poland belong to the least in Europe (GutryKorycka et al. 2014). Hence, assessment of meteorological and hydrological drought occurrence threat is an important issue. The proposed nomograms may be utilized for purposes of that threat monitoring.

The relationship between meteorological and hydrological types of drought has not been assessed with use of the standardized drought indices in the Vistula basin so far. This relationship turned out to be stronger in the regions with large water intake from the river. Such conclusions could be found thanks to the new approach to the standardized index method, i.e., assessing the relationships in particular subcatchments.

\section{Conclusions}

The main objectives of the work were to describe the Vistula basin in terms of the occurrence of 
meteorological and hydrological droughts observed in various sections of the Vistula river and to identify their mutual relations. It was assumed that the main factor causing hydrological drought is the occurrence of a long period of low precipitation, or, particularly, of no precipitation. Large rivers do not always react to short-term meteorological droughts due to the hydrological inertia of the basin. Only under the influence of several months of low precipitation, or lack thereof, do signs of hydrological drought appear.

Analysis of meteorological and hydrological droughts was carried out based on the values of the standardized indices (SPI, SWI, and SRI) in the period 1981-2010. The index method which was used allowed the joint method to be used in determining the dates of occurrence of both droughts in the multi-year study period and the same drought parameters to be calculated. This task was performed over three time scales of 12 , 24, and 48 months.

The literature and the authors' own research have shown that in many cases, where meteorological droughts were observed, the Vistula river basin was part of a much larger drought zone covering several to adozen-or-more countries in Europe. The spatial distribution of meteorological droughts was similar to the distribution of precipitation; they occurred earliest in the lowlands, and latest in the Carpathian Foothills. It is worth remembering here that the threshold values for sum of precipitation differed significantly across the entire river basin.

The effects of reduced precipitation in the Vistula basin were observed in changes in water levels and runoff at the measurement stations. During summer and early-autumn meteorological droughts, water levels and runoff were clearly decreasing. The high correlation coefficient values of SPI to SWI and of SPI to SRI in successive months and on the yearly scale indicate the influence of precipitation on the adopted hydrological parameters. Relationships limited to periods of concurrent occurrence of both types of drought were weaker, and in some cases, especially SPI to SWI, were very weak or exhibited no relationship.

The obtained research material has significantly broadened the current understanding of the threat of meteorological drought in the Vistula basin and its potential effects in the form of hydrological drought on the Vistula River. The relationships identified between droughts were not always unambiguous, and the probable cause was the influence of external factors.

\section{Compliance with ethical standards}

Conflict of interest The authors declare that they have no conflict of interest.

Open Access This article is distributed under the terms of the Creative Commons Attribution 4.0 International License (http:// creativecommons.org/licenses/by/4.0/), which permits unrestricted use, distribution, and reproduction in any medium, provided you give appropriate credit to the original author(s) and the source, provide a link to the Creative Commons license, and indicate if changes were made.

\section{References}

Al-Faraj, A. M. F., Scholz, M., \& Tigkas, D. (2014). Sensitivity of surface runoff to drought and climate change: Application for Shared River basins. Water, 6, 3033-3048. https://doi. org/10.3390/w6103033.

Andréasson, J., Bergström, S., Carlsson, B., Graham, P. L., \& Lindström, G. (2004). Hydrological change - Climate change impact simulations for Sweden. Ambio, 33(4-5), 228-234.

Bachmair, S., Svennson, C., Hannaford, J., Barker, L. J., \& Stahl, K. (2015). A quantitative analysis to objectively appraise drought indicators and model drought impacts. Hydrology and Earth System Sciences, 12, 9437-9488. https://doi. org/10.5194/hessd-12-9437-2015.

Bąk, B. (2006). Wskaźnik standaryzowanego opadu SPI jako kryterium oceny suszy rolniczej na glebach o różnej retencji użytecznej [Standardized precipitation index SPI as the criterion of agricultural drought in soils of different water retention capacity]. Dissertation, Institute of Land Reclamation and Grassland Farming, Falenty: Poland.

Bąk, B., \& Kubiak-Wójcicka, K. (2016). Assessment of meteorological and hydrological drought in Torun (central Poland town) in 1971-2010 based on standardized indicators. In P. Gastescu \& P. Bretcan (Eds.), 3rd International Conference Water Resources and wetlands Conference proceedings. (pp. 164-170). Tulcea: Romania.

Bąk, B., \& Kubiak-Wójcicka, K. (2017). Impact of meteorological drought on hydrological drought in Torun (central Poland) in the period of 1971-2015. Journal of Water and Land Development, 32(I-III), 3-12. https://doi.org/10.1515/jwld2017-0001.

Barker, L. J., Hannaford, J., Chiverton, A., \& Svensson, C. (2015). From meteorological to hydrological drought using standardised indicators. Hydrology and Earth System Sciences, 12, 12827-12875. https://doi.org/10.5194/hessd12-12827-2015.

Bartczak, A., Glazik, R., \& Tyszkowski, S. (2014). The application of Box-Cox transformation to determine the Standardised Precipitation Index (SPI), the Standardised Discharge Index (SDI) and to identify drought events: case study in eastern Kujawy (central Poland). Journal of Water 
and Land Development, 22, 3-15. https://doi.org/10.2478 jwwld-2014-0017.

Blauhut, V., Gudmundsson, L., \& Stahl, K. (2015). Towards panEuropean drought risk maps: Quantifying the link between drought indices and reported drought impacts. Environmental Research Letters, 10, 1-10. https://doi.org/10.1088/17489326/10/1/014008.

Bordi, I., Fraedrich, K., \& Sutera, A. (2009). Observed drought and wetness trends in Europe: An update. Hydrology and Earth System Sciences, 13, 1519-1530.

Cetin, M. (2015). Determining the bioclimatic comfort in Kastamonu City. Environmental Monitoring and Assessment, 187(10), 640. https://doi.org/10.1007/s10661015-4861-3.

Cetin, M., Adiguzel, F., Kaya, O., \& Sahap, A. (2018a). Mapping of bioclimatic comfort for potential planning using GIS in Aydin. Environment, Development and Sustainability, 20(1), 361-375. https://doi.org/10.1007/s10668-016-9885-5.

Cetin, M., Sevik, H., Canturk, U., \& Cakir, C. (2018b). Evaluation of the recreational potential of Kutahya urban forest. Fresenius Environmental Bulletin, 27(5), 2629-2634.

Cetin, M., Zeren, I., Sevik, H., Cakir, C., \& Akpinar, H. (2018c). A study on the determination of the natural park's sustainable tourism potential. Environmental Monitoring and Assessment, 190(3), 167. https://doi.org/10.1007/s10661018-6534-5.

Cyberski, J., Grześ, M., Gutry-Korycka, M., Nachlik, E., \& Kundzewicz, Z. W. (2006). History of floods on the river Vistula. Hydrological Sciences Journal, 51(5), 799-817. https://doi.org/10.1623/hysj.51.5.799.

Dobrovolski, S. G. (2015). World droughts and their time evolution: Agricultural, meteorological, and hydrological aspects. Water Resources, 45(2), 147-158. https://doi.org/10.1134 /S0097807815020049.

Doroszewski, A., Jóźwicki, T., Wróblewska, E., \& Kozyra, J. (2014). Susza rolnicza w Polsce w latach 1961-2010 [Agricultural drought in Poland in years 1961-2010]. Puławy, 2014. Available online: http://www.iung.pulawy. pl/images/wyd/Susza\%20rolnicza\%20w\%20Polsce.pdf.

Fal, B. (2007). Niżówki na górnej i środkowej Wiśle [Droughts in the upper and middle Vistula]. Gospodarka Wodna, 2, 72-81.

Folland, C. K., Hannaford, J., Bloomfield, J. P., Kendon, M., Svensson, C., Marchant, B. P., Prior, J., \& Wallace, E. (2015). Multi-annual droughts in the English Lowland: a review of their characteristics and climate drivers in the winter half-year. Hydrology and Earth System Sciences, 19, 2353-2375. https://doi.org/10.5194/hess-19-2353-2015.

GUS, Główny Urząd Statystyczny [Central Statistical Office]. Environment (2015). Available online: http://stat.gov. p 1 / o b s z a r y - t e m a t y c z n e / s r o d o w i s k oenergia/srodowisko/ochrona-srodowiska-2015,1,16.html (accessed on 21 November 2017).

Gutry-Korycka, M., Sadurski, A., Kundzewicz, Z. W., PociaskKarteczka, J., \& Skrzypczyk, L. (2014). Zasoby wodne a ich wykorzystanie [Water resources and their use]. Nauka, 1/2014, 77-98. Available online: http://www.pan.poznan. pl/nauki/N11407Gutry.pdf. Accessed 15 Nov 2017.

Haslinger, K., Koffler, D., Schöner, W., \& Laaha, G. (2014). Exploring the link between meteorological drought and streamflow: Effects of climate catchment interaction. Water
Resources Research, 50, 2468-2487. https://doi.org/10.1002 /2013WR015051.

Hong, N. M., Lee, T. Y., \& Chen, Y. J. (2016). Daily weather generator with drought properties by copulas and standardized precipitation indices. Environmental Monitoring and Assessment, 188, 383. https://doi.org/10.1007/s10661-0165395-z.

Kępińska-Kasprzak, M. (2015). Susze hydrologiczne w Polsce $i$ ich wplyw na gospodarowanie woda [Hydrological drought in Poland and their influence on the water management]. Bogucki Wydawnictwo Naukowe: Poznań.

Kleczkowski, A. S. (1990). Mapa Obszarów Głównych Zbiorników Wód Podziemnych (GZWP) w Polsce wymagajacych szczególnej ochrony [The Map of the Critical Protection Areas (CPA) of the Major Groundwater Basins (MGWB) in Poland] 1: 500000 . Akademia GórniczoHutnicza: Kraków.

Kubiak-Wójcicka, K. (2012). Charakterystyka niżówek na Wiśle w Toruniu [The characteristics of low water levels on the Vistula River in Torun]. In W. Marszelewski (Ed.), Gospodarowanie woda $w$ warunkach zmieniajacego sie środowiska (pp. 85-93). Toruń: Wydawnictwo Naukowe Uniwersytetu Mikołaja Kopernika.

Kubiak-Wójcicka K., (2018). Flow characteristics of the Vistula river at the Tczew gauging station in 1951-2010 based on Flashiness Index. In P. Gastescu \& P. Bretcan (Eds.), 4rd International Conference Water Resources and wetlands Conference proceedings. (pp. 119-129). Tulcea: Romania.

Kubiak-Wójcicka, K., Chodkowska-Miszczuk, J., \& Rogatka, K. (2017). Integration or disintegration of the ecological and urban functions of the river in the city? A polish perspective. Transylvanian Review of Administrative Sciences, 52, 59-76. https://doi.org/10.24193/tras.52E.4 http://www.rtsa. ro/tras/index.php/tras/article/view/534.

Kundzewicz, Z. W. (2009). Adaptation to floods and droughts in the Baltic Sea basin under climate change. Boreal Environment Research, 14, 193-203.

Łabędzki, L. (2017). Categorical forecast of precipitation anomaly using the standardized precipitation index SPI. Water, 9, 8. https://doi.org/10.3390/w9010008.

Li, J., Zhou, S., \& Hu, R. (2016). Hydrological drought class transition using SPI and SRI time series loglinear regression. Water Resources Management, 30, 669-684. https://doi. org/10.1007/s11269-015-1184-7.

Ljubenkov, I., \& Cindrić Kalin, K. (2016). Evaluation of drought using standardised precipitation and flow indices and their correlations on an example of Sinjsko polje. Gradevinar, 68(2), 135-143. https://doi.org/10.14256/JCE.1337.2015.

Loukas, A., \& Vasiliades, L. (2004). Probabilistic analysis of drought spatiotemporal characteristics in Thessaly region, Greece. Natural Hazards and Earth System. Science, 4, 719-731 SRef-ID: 1684-9981/nhess/2004 4-719.

Marosz, M., Wójcik, R., Biernacik, D., Jakusik, E., Pilarski, M., Owczarek, M., \& Miętus, M. (2011). Zmienność klimatu Polski od połowy XX wieku. Rezultaty projektu KLIMAT [Poland's climate variability 1951-2008. KLIMAT project's results]. Prace i Studia Geograficzne, 47, 51-66.

McKee, T. B., Doesken, N. J., \& Kleist, J. (1995). Drought monitoring with multiple time scales. Preprints of the 9th Conference Of Applied Climatology, 15-20 January 1995, Dallas, Texas, pp. 233-236. 
Meresa, H. K., Osuch, M., \& Romanowicz, R. (2016). Hydrometeorological drought projections in to the 21-st century for selected polish catchments. Water, 8, 206. https://doi. org/10.3390/w8050206.

Mishra, S., \& Nagarajan, R. (2013). Hydrological drought assessment in Tel river basin using standardized water level index (SWI) and GIS based interpolation techniques. International Journal of Conceptions on Mechanical and. Civil Engineering, 1(1), 2357-2760.

Mishra, A. K., \& Singh, V. P. (2010). A review of drought concept. Journal of Hydrology, 391, 202-216. https://doi.org/10.1016 /j.jhydrol.2010.07.012.

Nalbantis, I., \& Tsakiris, G. (2009). Assessment of hydrological drought revisited. Water Resources Management, 23, 881897. https://doi.org/10.1007/s11269-008-9305-1.

Nam, W.-H., Hayes, M. J., Svoboda, M. D., \& Tadesse, T. (2015). Drought hazard assessment in the context of climate change for South Korea. Agricultural Water Management, 160, 106117. https://doi.org/10.1016/j.agwat.2015.06.029.

Pawłowski, B. (2009). Long-term variability in the course of ice phenomena on the Vistula River in Torun. Bulletin of Geography - Physical Geography Series, 1, 91-102.

Rimkus, E., Valiukas, D., Kažys, J., Gečaite, I., \& Stonevičius, E. (2012). Dryness dynamics of the Baltic Sea region. Baltica, 25(2), 129-142. https://doi.org/10.5200/baltica.2012.25.13.

Rimkus, E., Stonevičius, E., Korneev, V., Kažys, J., Valiuškevičius, G., \& Pakhomau, A. (2013). Dynamics of meteorological and hydrological droughts in the Neman river basin. Environmental Research Letters, 8. https://doi. org/10.1088/1748-9326/8/4/045014.

Sahoo, R. N., Dutta, D., Khanna, M., Kumar, N., \& Bandyopadhyay, S. K. (2015). Drought assessment in the Dhar and Mewat Districs of India using meteorological and remote-sensing derived indices. Natural Hazards, 77, 733751. https://doi.org/10.1007/s11069-015-1623-z.

Santos, C. A. G., Brasil Neto, R. M., Passos, J. S. A., \& da Silva, R. M. (2017). Drought assessment using a TRMM-derived standardized precipitation index for the upper São Francisco River basin, Brazil. Environmental Monitoring and Assessment, 189, 250. https://doi.org/10.1007/s10661-0175948-9.

Šebenik, U., Brilly, M., \& Šraj, M. (2017). Drought analysis using the standardized precipitation index (SPI). Acta Geographica Slovenica, 57(1), 31-49. https://doi.org/10.3986/AGS.729.

Seftigen, K., Linderholm, H. W., Drobyshev, I., \& Niklasson, M. (2013). Reconstructed drought variability in southeastern Sveden since the 1650 s. International Journal of Climatology, 33, 2449-2458.

Shukla, S. \& Wood, A. W. (2008). Use of a standardized runoff index for characterizing hydrologic drought. Geophysical Research Letters, 35. https://doi.org/10.1029/2007 GL032487.
Somorowska, U. (2009). Wzrost zagrożenia suszą hydrologiczną w różnych regionach geograficznych Polski w XX wieku [Increase in the hydrological drought risk in different geographical regions of Poland in the 20th century]. Prace $i$ Studia Geograficzne, 43, 97-114.

Spinoni, J., Naumann, G., Vogt, J. V., \& Barbosa, P. (2015). The biggest drought events in Europe from 1950 to 2012. Journal of Hydrology: Regional Studies, 3, 509-524. https://doi. org/10.1016/j.ejrh.2015.01.001.

Tokarczyk, T., \& Szalińska, W. (2014). Combined analysis of precipitation and water deficit for drought hazard assessment. Hydrological Sciences Journal, 59(9), 1675-1689. https://doi.org/10.1080/02626667.2013.862335.

Tsakiris, G., Pangalou, D., \& Vangelis, H. (2006). Regional drought assessment based on the reconnaissance drought index (RDI). Water Resources Management, 21, 821-833. https://doi.org/10.1007/s11269-006-9105-4.

van Loon, A. F., \& Laaha, G. (2015). Hydrological drought severity explained by climate and catchment characteristics. Journal of Hydrology, 526, 3-14. https://doi.org/10.1016/j. jhydrol.2014.10.059.

Vicente-Serrano, S. M., \& López-Moreno, J. I. (2005). Hydrological response to different time scales of climatological drought: An evaluation of the standardized precipitation index in a mountainous Mediterranean basin. Hydrology and Earth System Sciences, 9, 523-533 SRef-ID: 1607-7938/ hess/2005-9-523.

Vicente-Serrano, S. M., Beguería, V., Lorenzo-Lacruz, J., Camarero, J. J., López-Moreno, J. I., Azorin-Molina, C., Revuelto, J., Morán-Tejeda, E., \& Sanchez-Lorenzo, A. (2012). Performance of drought indices for ecological, agricultural, and Hydrological Applications. Earth Interactions, 16(10), 1-27.

Vido, J., Tadesse, T., Šustek, Z., Kandrík, R., Hanzelová, M., Škvarenina, J., Škvareninová, J., \& Hayes, M. (2015). Drought occurrence in central European mountainous region (Tatra National Park, Slovakia) within the period 1961-2010. Hindawi Publishing Corporation. Advances in Meteorology, 2015, 1-8. https://doi.org/10.1155/2015/248728.

World Meteorological Organization (WMO). (2012). Standardized precipitation index. User guide (p. 24). Switzerland: Geneva http://www.worldairco. org/IJCMCE/December2013Paper23.pdf.

Zeleňáková, M., Vido, J., Portela, M. M., Purcz, P., Blištán, P., Hlavatá, H., \& Hluštik, P. (2017). Precipitation trends over Slovakia in the period 1981-2013. Water, 9. https://doi. org/10.3390/w9120922.

Zou, L., Xia, J., She, D., \& Zhan, Ch. (2018). Identification of hydrological drought in eastern China using a timedependent drought index. Water, 10. https://doi.org/10.3390 /w10030315. 